\title{
D YSKUSJE I POLEMIKI
}

\author{
Seweryn Szczepański
}

\section{ANTONIUS DE BUTRIO - WCALE NIE TAKI NIEZNANY (NA MARGINESIE ARTYKUŁU KS. TOMASZA GARWOLIŃSKIEGO)}

Z dużym zainteresowaniem zapoznałem się z artykułem ks. Tomasza Garwolińskiego na temat odręcznych zapisek Mikołaja Kopernika zachowanych na starodrukach znajdujących się w Bibliotece olsztyńskiego „Hosianum”, zamieszczonym w Komunikatach Mazursko-Warmińskich ${ }^{1}$. Dzieląc z autorem przywołanego tékstu zainteresowania starodrukami, a ponadto interesując się kulturą włoskiego średniowiecza, lektura zarówno pod względem merytorycznym, filologicznym oraz metodycznym niewątpliwie poszerzyła moją dotychczasową wiedzę. Pewne zaskoczenie jednak wzbudziła u mnie informacja na temat Antoniusa de Butrio - autora dzieła z dziedziny prawa kanonicznego, znanego w skrócie jako Consilia. Księga ta, wydana w Rzymie w 1472 r., znajdowała się w posiadaniu Kopernika. Ks. Garwoliński słusznie podaje, że jest to pierwsze wydanie dzieła i zarazem najstarsze w zbiorach polskich. Kolejne, jak zauważa autor, znajdują się w bibliotekach: Jagiellońskiej w Krakowie (wyd. z 1479 r. i wyd. z 1493 r.) oraz w Miejskiej Bibliotece Publicznej w Bydgoszczy (wyd. z 1498 r.). ${ }^{2}$ Trudno jednak zaakceptować znajdujące się dwa akapity niżej stwierdzenie ks. Garwolińskiego, że „Antonius de Butrio był kanonistą, ale nie ma o nim więcej informacji” (s. 415).

Pobieżne choćby prześledzenie biogramów i kronik ${ }^{3}$, literatury fachowej ${ }^{4}$, encyklopedii i leksykonów ${ }^{5}$ a nawet zasobów Internetu ${ }^{6}$ pokazuje wyraźnie, że

${ }^{1}$ T. Gawroliński, Stan badań nad odręcznymi zapiskami Mikołaja Kopernika w starych drukach Biblioteki Wyższego Seminarium Duchownego Metropolii Warmińskiej „Hosianum”w Olsztynie, KMW, 2015, nr 3 (289), ss. 409-431.

${ }^{2}$ Warto dodać, że znane są też inne wydania tego dzieła z lat 1474 (Rzym); 1492 (Pavia); 1541 (Lyon); 1575, 1582 (Wenecja) znajdujące się w bibliotekach europejskich.

${ }^{3}$ Notizie degli scrittori Bolognesi da Giovanni Fantuzzi, t. II, Bologna 1782, ss. 353-357; Annali della cittŕ di Bologna. Dalla sua origine al 1796 compilati da Salvatore Muzzi, Bologna 1845, s. 281 i n.

${ }^{4}$ J. F. v. Schulte, Die Geschichte der Quellen und Literatur des canonischen Rechts, Bd. 2, Stuttgart 1877, ss. 289-294; T. Wetzstein, Heilige vor Gericht. Das Kanonisationsverfahren im Europäischen Spätmittelalter, Köln-Weimar-Wien 2004, s. 61 i n; R. L. Guidi, Dibattito sulluomo nel Quattrocento, Roma 1998, ss. 206-207; T. F. Mayer, The Roman Inquisition: Trying Gallileo, Philadelphia 2015, ss. 81-84, 91-95.

${ }^{5}$ L. Prosdocimi, Antonio da Budrio, w: Dizionario Biografico degli Italiani, t. 3, Roma 1961, ss. 541-542.

${ }^{6}$ Por. choćby edycja on-line DBI z hasłem Antonio da Budrio: http://www.treccani.it/enciclopedia/antonio-da-budrio_(Dizionario-Biografico)-(Dizionario-Biografico)/ (dostęp 12-09-2016). 
autor zbioru prawnego Consilia Antonius de Butrio (aka Antonio da Budrio) wcale nie jest postacią aż tak bardzo tajemniczą.

Warto w tym miejscu, gwoli uzupełnienia, przytoczyć choćby kilka faktów z życia bolońskiego kanonisty. Wiemy, że urodził się w roku 1338 w położonym nieco ponad $30 \mathrm{~km}$ na wschód od Bolonii miasteczku Budrio. Ojcem jego był Bartolino Biagi. Dość późno, bo dopiero w 1386 r., Antonius ukończył studia prawnicze w Bolonii, a 12 lipca 1387 r. otrzymał tytuł doktora prawa kanonicznego, od tego roku też poświadczony jest w radzie miejskiej Bolonii. Peregrynował w poszukiwaniu dobrej posady do Perugii, gdzie administrował diecezją, w 1391 r. już wykładał na uczelni w Bolonii, a od 17 czerwca poświadczony jest też jako członek nadzwyczajny kolegium doktorskiego prawa kanonicznego, obejmując pełnoprawne członkostwo dopiero 29 listopada 1399 r. W międzyczasie (lata 1398-1399) znajdujemy go jako profesora we Florencji. Później teź przez krótki czas (lata 1402-1403) wykładał prawo kanoniczne w Ferrarze. Uczestniczył także w negocjacjach między antypapieżem Benedyktem XIII a papieżem Grzegorzem XII w 1407 r. Była to ostatnia ważna misja de Butrio, gdyż zmarł po powrocie do Bolonii, 4 października 1408 r., przeżywszy 70 lat. Pochowano go w kościele św. Michała in Bosco. W pamięci potomnych miał pozostać jako wybitny myśliciel, jurysta oraz bardzo dobry nauczyciel (m.in. Francesca Zabarẻli) o czym też informować miało jego epitafium.

Ze swego małżeństwa z Margheritą di Lambertino Balduini miał dwie córki, a zapewne też syna. Antonius de Butrio zasłynął przede wszystkim jako jeden $\mathrm{z}$ autorów wielokrotnie wznawianego wielotomowego dzieła Lectura o Commentaria in quinque libros Decretalium, także kontynuacji „komentarzy” w postaci Commentaria in Sextum oraz wspomnianych już Consilia, które to dzieło znajdowało się właśnie w bibliotece Kopernika. Ponadto w jego dorobku znajdujemy też inne prace, napisane wspólnie z innymi prawnikami, takie jak: Speculum confessione (Leuven 1481-1483) oraz szereg dzieł prawniczych: De iure patronatus, De emptionibus et venditionibus, De notorio, De symonia oraz Repertorium de iure civili?.

Mimo że niniejszy szkic nie rości sobie najmniejszych pretensji do stanowienia choćby przyczynku do biografii Antoniusa da Butrio, a tym bardziej umniejszania odbioru bardzo cennego artykułu ks. Tomasza Garwolińskiego, to mam nadzieję, że choć trochę przybliżył postać tego - jak się okazuje - wcale nie nieznanego przedstawiciela przełomu włoskiego trecento i quattrocento, z którego dorobku korzystał też Mikołaj Kopernik.

${ }^{7}$ Pełną bibliografię prac podaje L. Prosdocimi, op. cit., s. 542. Też: http://www.treccani.it/enciclopedia/ antonio-da-budrio_(Dizionario-Biografico)-(Dizionario-Biografico)/ (dostęp 12-09-2016). 